\author{
JINOTEP Vol 6 (2) (2020): 81-88 \\ DOI: $10.17977 / u m 031 v 6 i 22020$ p081
}

JINOTEP (Jurnal Inovasi Teknologi Pembelajaran)

Kajian dan Riset Dalam Teknologi Pembelajaran

http://journal2.um.ac.id/index.php/jinotep/index

\title{
PENGEMBANGAN KURIKULUM MUATAN LOKAL INSTRUKSIONAL TARI REOG KENDANG DI SEKOLAH DASAR NEGERI 2 PUCANGAN
}

\author{
Andhika Ramadhani Febriansyah, Agus Wedi, Arafah Husna \\ Jurusan Teknologi Pendidikan, Fakultas Ilmu Pendidikan, Universitas Negeri Malang
}

\section{Article History \\ Received: 12-05-2019 \\ Accepted:20-06-2019 \\ Published:30-04-2020}

\section{Keywords}

Pengembangan, Kurikulum Muatan Lokal,Tari Reog Kendang

\begin{abstract}
Abstrak
Tujuan dikembangkannya kurikulum ini adalah menghasilkan produk kurikulum muatan lokal Reog Kendang yang tervalidasi sehingga layak dugunakan dalam pembelajaran muatan lokal di SDN 2 Pucangan. Validasi produk kurikulum muatan lokal ini dilakukan oleh ahli kurikulum, ahli materi dan guru muatan lokal. Penelitian ini menggunakan model Beuchamp's dengan pengumpulan data menggunakan metode kuantitatif (instrumen ahli kurikulumk, ahli materi) dan kualitatif (observasi dan wawancara), subjek penelitian pengembangan kurikulum muatan lokal ini yaitu SDN 2 Pucangan. Berdasarkan hasil yang diperoleh dari validasi yang dilakukan oleh ahli kurikulum dan ahli materi dapat disimpulkan bahwa silabus kurikulum muatan lokal tari Reog Kendang dapat dikatagorikan valid. Selain itu juga dari hasil validasi yang diperoleh dari guru muatan lokal bahwa RPP kurikulum muatan lokal tari Reog Kendang tergolong dalam katagori valid. Jadi dapat disimpulkan bahwa kurikulum muatan lokal tari Reog Kendang ini layak digunakan di SDN 2 Pucangan.
\end{abstract}

\begin{abstract}
The purpose of developing this curriculum is to produce a validated curriculum product for local Reog Kendang content so that it is suitable to be used in learning local content at SDN 2 Pucangan. Validation of local content curriculum products is carried out by curriculum experts, material experts and local content teachers. This study uses the Beuchamp's model with data collection using quantitative methods (curriculum expert instruments, material experts) and qualitative (observation and interviews), the subject of this local curriculum development research is SDN 2 Pucangan. Based on the results obtained from the validation carried out by curriculum experts and material experts, it can be concluded that the curriculum syllabus of local content of Reog Kendang dance can be categorized as valid. In addition, from the results of validation obtained from the local content teacher that the lesson plan curriculum of local content drum reog dance is classified as a valid category. So it can be concluded that the curriculum of the local content of the Reog Kendang dance is worthy of being used at Pucangan 2 Elementary School.
\end{abstract}

Corresponding author :

Andhika Ramadhani Febriansyah

Universitas Negeri Malang

Jalan Semarang 5 Malang

E-mail: Andhikaf394@gmail.com
2020 Universitas Negeri Malang p-ISSN 2406-8780 e-ISSN 2654-7953 


\section{PENDAHULUAN}

Lembaga pendidikan memegang peranan penting dalam pendidikan yang ada di masyarakat, kurikulum merupakan pedoman dalam pelaksanaan dan menjadi sebuah komponen penting dalam suatu rancangan pada sistem pendidikan nasional. Sedangkan Menurut B. Othel Smisth, W.O. Stanley dan J. Harlan Shores (Zaenal Arifin 2014) memandang kurikulum sebgai a sequences of potensial experiences set up in the school for the purpose of the dispiciplining children and youth in group ways of thingking and acting. Pengertian tersebut menunjukkan kurikulum bukan hanya mata pelajaran, tetapi juga pengalaman yang dapat di berikan kepada peserta didik Kurikulum yang ada di sekolah bisa digunakan oleh pemerintah untuk melestarikan potensi lokal daerah dengan cara masukkannya ke dalam sebuah mata pelajaran yang terdapat dalam kurikulum muatan lokal sekolah. Hal ini di karenakan lembaga pendidikan mempunyai wewenang untuk mengelola dan mengembangkan kurikulum sesuai dengan potensi daerah masing-masing. kurikulum muatan lokal adalah materi pelajaran dan pengenalan berbagai kearifan lokal daerah setempat. Menurut (Toenlioe 2017) kurikulum muatan lokal dapat di terapkan mulai dari tingkat SD yang isinya disesuaikan dengan tingkat akademik siswa, sehingga bersifat holistik, mulai dari hulu hingga hilir. Pada penerapannya karena pendidikan untuk siswa dan bukan dari siswa untuk pendidikan, maka penerapan kurikulum muatan lokal ini harus disesuikan dengan kondisi psikologis akademik siswa itu sendiri.

Jawa Timur memiliki berbagai kebudayaan lokal daerah yang masih hidup dan dipertahankan oleh masyarakat setempat. Salah satunya yaitu Tari Reog Kendang. Kebudayaan tari Reog Kendang merupakan kesenian tari tradisional yang berasal dari daerah kabupaten Tulungagung. Tari Reog Kendang ini sangatlah berbeda dengan tari yang ada di daerah lainnya. Tari Reog Kendang memiliki ciri khas dan keunikan tersendiri dari setiap keindahan gerakan penarinya (Widwi 2017). Dalam sejarahnya Seni Tari Reog Kendang asli daerah Tulungagung ini terbentuk dari terinspirasi oleh permainan kendang prajurit Bugis dalam kesatuan Laskar Trunojoyo. Pada zaman dahulu diceritakan para prajurit menggunakan tam-tam atau kendang kecil yang digendong, oleh karena itu tari Reog Kendang ini menggunakan alat musik sejenis tifa atau jimbe yang di padukan dengan kesenian jaranan.

Dalam pertunjukannya, Reog Kendang Tulungagung ini ditampilkan secara berkelompok oleh enam orang penari yang masing-masing dari mereka membawa kendang atau masyarakat tulungagung memanggilnya dengan sebutan gempluk/dhogdhog. Manurut Rokhim Gerak tari Reyog kendang didominasi oleh gerak kaki, kadang gerak yang dilakukan menyerupai orang pincang terdapat pada gerak andul, dan seperti orang deyog terdapat pada gerak menthokan (Rokhim 2013) gerakan tersebut mempunyai istilah sederhana namun didalamnya memiliki arti yang sangat dalam.

Selain itu ada beberapa versi gerakan tambahan yaitu gerakan badan, pundak, leher dan kepala yang disertai dengan mimik muka yang ekspresif. Sambil menari, penari memainkan kendang mereka selaras dengan pengiring musiknya. Gerakan dalam Reog Kendang ini di bedakan menjadi berbagai jenis, diantaranya seperti gerak baris, gerak andul, gerak menthokan, gerak gedjoh bumi dan masi banyak lainnya, Sehingga dapat dikatakan bahwa seni tari Reog Kendang ini memiliki keindahan dan keunikan gerak di dalamnya. Dan sangat disayangkan apabila salah satu kesian ini tidak dikembangkan dan tidak diajarkan kepada generasi muda.

Melihat dari pentingnya melestarikan budaya kearifan lokal daerah, maka di perlukan sebuah langkah untuk mengatasi permasalahan tersebut. Utari menjelaskan kearifan lokal merupakan kecendikiaan terhadap kekayaan setempat/suatu daerah berupa pengetahuan, kepercayaan, norma, adat istiadat, kebudayaan, wawasan dan sebagainya yang merupakan warisan dan dipertahankan sebagai sebuah identitas dan pedoman dalam mengajarkan kita untuk bertindak secara tepat dalam kehidupan 
(Utari, Degeng, and Akbar 2016). Banyak cara dapat digunakannya salah satunya yaitu melalui lembaga pendidikan. Menurut pusat data dan statistik Kemendikbud tahun 2017/2018 Indonesia memiliki jumlah lembaga pendidikan yaitu 307.655 , dari jumlah lembaga pendidikan yang di miliki dan tersebar di seluruh daerah yang ada di Indonesia tentunya pelestarian kebudayaan melalui lembaga pendidikan dirasa sangat begitu efektif dan tepat. Karena sesuai dengan salah satu peranan dari kurikulum yang ada disekolah itu sendiri yaitu menurut (Zaenal Arifin 2014) peranan kurikulum untuk mewariskan, mentransmisikan, dan menafsirkan nilai-nilai sosial budaya masa lampau yang ada dikalangan masyarakat. Sehingga sekolah sebagai pranata sosial harus dapat mempengaruhi dan membimbing peserta didiknya.

Sekolah merupakan lembaga pendidikan yang dicanangkan kementrian pendidikan nasional untuk di terapkannya sebuah pendidikan karakter pada semua jenjangnya, namun porsinya akan lebih besar di berikan pada Sekolah Dasar. Menurut (Ahmadi, Amri, and Elisah 2012) pada jenjang Sekolah Dasar pendidikan karakter memiliki porsi mencapai 60 persen di bandingkan dengan pendidikan lainnya. Pendidikan karakter yang termudah dilakukan adalah ketika anak-anak masi duduk di Sekolah Dasar yang terdapat pendidikan kesenian di dalamnya, seperti halnya SDN 2 Pucangan. Pendidikan kesenian di sekolah tersebut sudah lama dilaksanakan dibuktikan dengan beberapa prestasi salah satunya ikut serta dalam pemecahan rekor muri 2400 penari Reog Kendang Tulungagung pada tahun 2015. Namun prestasi ini kurang begitu di dukung karena belum ada kurikulum terkait pelajaran kesenian tari Reog Kendang di sekolah tersebut

Masalah pengembangan kurikulum muatan lokal yang ada di sekolah dasar kurang begitu di perhatikan melihat dari rendahnya kualitas guru dalam bidang kesenian dan juga kurang diminatinya pelajaran kesenian dan kebudayaan yang ada di sekolah. Sebenarnya pada dasarnya pendidikan seni di sekolah memiliki tujuan yang baik bagi siswa rosalla menjelaskan pendidikan seni tari di sekolah memiliki tujuan untuk memfasilitasi berbagai potensi yang dimiliki oleh siswa bukan untuk menjadikan siswa sebagai ahli seni tari sesuai dengan prinsip khusus yaitu prinsip yang berkenaan tentang tujuan pendidikan (Rosala 2017). Sekolah dasar itu sendiri merupakan jenjang pendidikan yang sangat menentukan bagi perkembangan anak dan bagi anak, seni merupakan bagian mendasar dari pendidikan dasar.

Berdasarkan hasil studi pendahuluan di SDN 2 Kauman di peroleh dari kepala sekolah menyebutkan bahwa seni tari Reog Kendang di SDN 2 kauman sudah diterapkan sejak 2012 namun dalam proses pelaksanaannya terdapat beberapa kendala yaitu salah satunya belum tersedianya kurikulum dalam proses belajar mengajar yang di sebabkan oleh kurangnya pemahaman guru muatan lokal dalam menyusun kurikulum seni tari Reog Kendang, dan khususnya belum tersedianya silabus pembelajaran yang merupakan sebuah dokumen penting dalam proses pembelajaran. Silabus merupakan sebuah rencana pembelajaran pada suatu dan/atau kelompok mata pelajaran/tema tertentu yang mencakup $\mathrm{SK}, \mathrm{KD}$, materi pembelajaran, kegiatan pembelajaran, indikator pencapaian kompetensi, penilaian, alokasi waktu, dan sumber belajar (Zubaidi 2015). Di SD Negeri 2 Pucangan sendiri telah dilengkapi fasilitas serta tenaga pengajar yang terampil di bidangnya. Sedangkan dalam bidang ini guru seni tari Reog Kendang di SDN 2 Pucangan berpendapat bahwa seni tari Reog Kendang diajarkan kepada siswa mulai dari kelas I sampai dengan kelas $\mathrm{V}$ dengan mengambil siswa yang berminat mengikuti ekstrakurikuler Tari Reog Kendang. Kegiatan ini telah ditunjang oleh fasilitas yang memadai sehingga menambah minat siswa dalam belajar seni Tari Reog Kendang.

Melihat dari pentingnya kurikulum muatan lokal di sekolah yang sangat bermanfaat bagi pelestarian kebudayaan daerah yang dikarenakan keberadaan mata pelajaran muatan lokal yang merupakan bentuk penyelenggaraan pendidikan yang tidak terpusat, sebagai upaya agar penyelenggaraan pendidikan di masingmasing daerah lebih meningkat relevansinya terhadap keadaan dan kebutuhan daerah yang 
84 JINOTEP (Jurnal Inovasi dan Teknologi Pembelajaran) Kajian dan Riset dalam Teknologi Pembelajaran Vol. 6, No. 2, April 2020, Hal. 81-88

bersangkutan (Purwanti 2013) dan jika ditinjau lagi dari ruang lingkup pelaksanaan kurikulum muatan lokal mewajibkan muatan lokal sebagai mata pelajaran inti dan disetarakan dengan mata pelajaran lainnya seperti pendidikan agama, pendidikan kewarga-negaraan, bahasa, matematika, IPA, IPS, seni budaya, pendidikan jasmani dan ketrampilan/kejuruan (Kairupan 2015). Sedangkan apabila melihat dari kondisi lingkungan SDN 2 Pucangan yang sebagaian penduduknya ahli dalam bidang kebudayaan seperti halnya turut andil dalam membangun seni tari Reog Kendang di wilayah Tulungagung yang menjadikan pengembangan kurikulum lebih efektif dan variatif di sekolah tersebut yang notabennya sekolah dasar, serta di dukung permendikbud nomor 79 tahun 2014 pasal 2 ayat 1 yang menjelaskan bahwa kurikulum muatan lokal yang diajarkan dengan tujuan membekali perserta didik dengan sikap, pengetahuan, dan keterampilan yang diperlukan untuk mengenal dan mencintai lingkungan alam, sosial, budaya, dan spiritual di daerah

Dengan adanya kurikulum muatan loka tari Reog Kendang yang sangat dibutukan di SDN 2 Pucangan dan untuk memecahkan masalah berkaitan dengan kurikulum muatan lokal yang ada di Sekolah tersebut, maka penulis tertarik untuk mengkaji masalah ini dengan mengambil judul "Pengembangan Kurikulum Muatan Lokal Instruksional Tari Reog Kendang Di Sekolah Dasar Negeri 2 Pucangan"

\section{METODE}

Pada penelitian pengembangan kurikulum muatan lokal seni tari Reog Kendang ini menggunakan salah satu dari model pengembangan kurikulum yaitu Beuchamp's System Model. Model pengembangan kurikulum ini di kembangkan oleh G.A. Beucamp, 1975 dalam (Zaenal Arifin 2014), mengemukakan terdapat lima langkah dalam pengembangan kurikulum, yaitu: 1) Penentuan arena atau cakupan wilayah pengembangan kurikulum, 2) Memilih dan mengikut sertakan personalia yang terlibat ke dalam pengembang kurikulum, 3) Pengorganisasian dan penentuan prosedur pelaksanaan kurikulum, 4) Pelaksanakan kurikulum secara sistematis, 5) Prosedur evaluasi kurikulum.

Dalam pengembangan kurikulum yang dikembangkan oleh G.A Beuchamp, peneliti mengacu dari langkah-langkah tahapan tersebut dalam melakukan pengembangan. Pada penelitian ini model tidak dilakukan uji coba di lapangan dikarenakan membutuhkan waktu dan perencanaan yang cukup lama, namun penelitian ini hanya sampai pembuatan pada wujud kurikulum dalam bentuk dokumen tertulis yang berdasar pada keputusan dan kebijakan beberapa ahli, yaitu ahli kurikulum dan ahli materi (seni tari Reog Kendang). Adapun langkah-langkah pengembangan kurikulum yaitu:

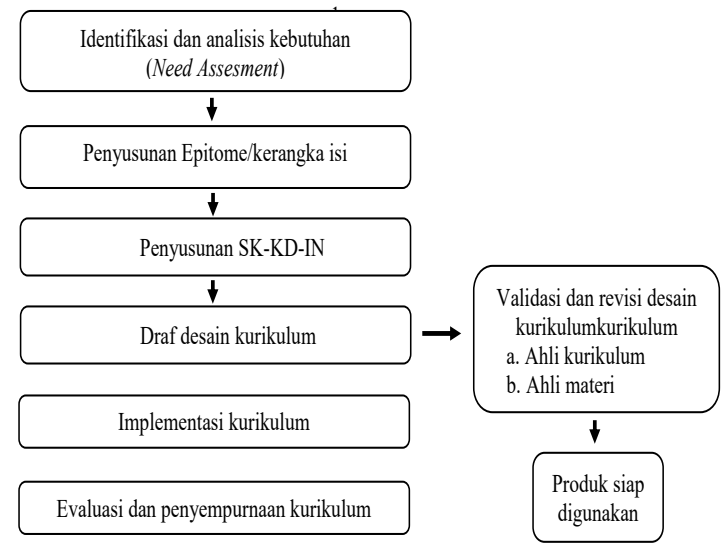

Gambar 1. Langkah-langkah penelitian

Jenis data dalam pengembangan kurikulum muatan ini menggunakan metode kualitatif dan kuantitatif dengan Teknik perolehan data yang berbeda. Dalam data kualitatif ini diperoleh dari hasil wawancara yang dilakukan kepada kepala sekolah, seniman tari Reog Kendang, dan guru muatan lokal SDN 2 Pucangan, sedangkan untuk data kuantitatif diperoleh dari hasil penilaian angket yang dilakukan oleh ahli kurikulum dan ahli materi untuk mengetahui tentang kesesuaian materi pengembangan kurikulum muatan lokal.

Analisis Data angket

Untuk teknik analisis data dalam pengembangan kurikulum muatan lokal tari Reog Kendang ini dilakukan sebagai berikut: 


\section{a. Teknik Analisi Data}

Pada tahap ini untuk menganalisis hasil data angket yang diperoleh dari ahli kurikulum dan ahli materi dengan menggunakan teknik presentase dan rumus sebagai berikut:

1) Rumus dalam mengolah data per item

$$
\mathrm{P}=\frac{x}{x i} \times 100
$$

Keterangan:

$\mathrm{P} \quad=$ Presentasi

$\mathrm{Xi}=$ Jumlah jawaban keseluruhan satu item

$\mathrm{x} \quad=$ Jumlah jawaban responden

$100 \%=$ Konstanta dalam seluruh item

2) Rumus dalam mengolah data keseluruhan

$$
\mathrm{P}=\frac{\sum x}{\sum x i} \times 100 \%
$$

Keterangan:

$$
\mathrm{P} \quad=\text { Presentasi }
$$

$100 \%=$ Konstanta dalam seluruh item

$\sum \mathrm{xi}=$ Jumlah keseluruhan nilia ideal dalam satu item

$\sum \mathrm{x}=$ Jumlah keseluruhan jawaban responden

\section{b. Interpretasi Data}

Setelah data diolah dengan menggunakan rumus diatas, maka hasil data yang diperoleh akan dicocokkan dengan kriteria kelayakan seperti berikut:

Kriteria Tingkat Kelayakan (Arikunto, 2006:274)

\begin{tabular}{llll}
\hline Kategori & $\begin{array}{l}\text { Skor } \\
\text { Persentase }\end{array}$ & $\begin{array}{l}\text { Tingkat } \\
\text { Valid }\end{array}$ & Ekuivalen \\
\hline A (4) & $76 \%-100 \%$ & Valid & $\begin{array}{l}\text { Layak } \\
\text { Cukup } \\
\text { B (3) }\end{array}$ \\
C (2) & $26 \%-50 \%$ & Kurang Valid & $\begin{array}{l}\text { Kurang } \\
\text { Layak }\end{array}$ \\
D (1) & $0 \%-25 \%$ & Tidak Valid & Tidak Layak \\
\hline
\end{tabular}

Pengembangan kurikulum muatan lokal yang dikembangkan ini dikatakan berhasil dan bisa diterapkan di sekolah apabila memenuhi kriteria minimal cukup layak dengan presentase 51\%$75 \%$.

\section{HASIL}

Pada Kurikulum muatan lokal tari Reog Kendang akan divalidasikan kepada beberapa ahli yang berkompeten didalamnya. Validasi ini meliputi silabus dan lima jenis RPP yang nantinya akan menjadi dasar dalam pelaksanaan kurikulum muatan lokal tari Reog Kendang.Untuk silabus di validasi oleh ahli kurikulum dari Dosen Teknologi Pendidikan Universitas Negeri Malang dan ahli materi dari guru muatan lokal Sekolah Dasar Negeri 2 Pucangan sedangkan untuk RPP divalidasikan oleh guru muatan lokal SDN 2 Pucangan. Tujuan dari validasi silabus dan RPP ini untuk mengukur tingkat validitas dan kelayakan produk ini untuk di terapkan di sekolah.

Berdasarkan validasi silabus oleh ahli materi dan ahli kurikulum diperoleh hasil seperti tabel di bawah ini:

Tabel 1. Hasil validasi ahli kurikulum dan ahli materi

\begin{tabular}{llcl}
\hline No & Validitor & Presentase & Katagori \\
\hline 1 & Ahli & $83,6 \%$ & Valid \\
& Kurikulum & & \\
2 & Ahli Materi & $91,66 \%$ & Valid
\end{tabular}

Berdasarkan tabel 1 dapat disimpulkan bahwa produk yang dikembangkan dinilai valid untuk diimplementasikan.

Berdasarkan validasi RPP oleh guru muatan lokal diperoleh hasil seperti dibawah ini:

Tabel 2. Hasil validasi RPP oleh guru

\begin{tabular}{llll}
\hline No & \multicolumn{1}{c}{ RPP } & Presentase & Katagori \\
\hline 1 & RPP 1 & $93,33 \%$ & Valid \\
2 & RPP 2 & $90 \%$ & Valid \\
3 & RPP 3 & $90 \%$ & Valid \\
4 & RPP 4 & $90 \%$ & Valid \\
5 & RPP 5 & $88,33 \%$ & Valid \\
6 & RPP 6 & $90 \%$ & Valid \\
\hline
\end{tabular}

Berdasarkan data pada tabel 2 dapat disimpulkan bahwa rata-rata validasi RPP oleh guru dinyatakan valid dengan persentase di atas $90 \%$. 
86 JINOTEP (Jurnal Inovasi dan Teknologi Pembelajaran) Kajian dan Riset dalam Teknologi Pembelajaran Vol. 6, No. 2, April 2020, Hal. 81-88

Kurikulum muatan lokal merupakan suatu program pendidikan yang isi dan media penyampaiannya dikaitkan dengan lingkungan alam, lingkungan sosial, dan lingkungan budaya serta kebutuhan daerah. Amalia menambahkan bahwa pengembangan kurikulum muatan lokal merupakan pengembangan konsep pendidikan yang juga sesuai dengan konsep dari Ki Hajar Dewantara yaitu Trikon yang berarti kebudayaan dapat ditempuh dengan melalui sikap yang diajarkan salah satunya dalam bidang pendidikan (Amaliah 2016).

Pengembangan kurikulum muatan lokal tari Reog Kendang ini sangat layak untuk dikembangkan karena dapat melestarikan dan mengembangkan kebudayaan asli daerah. Hal tersebut sesuai dengan dua penelitian sebelumnya, pertama yang dilakukan oleh (Pratama, Toenlioe, and Ulfa 2018) menyebutkan bahwa Negara Indonesia memiliki keanekaragaman di dalamnya dan perlu ditumbuhkan dengan baik, dilestarikan kepada anak-anak bangsa masa kini maupun masa depan dengan tujuan bangsa Indonesia tidak kehilangan ciri khasnya. Penelitian kedua dilakukan oleh (Zainul Arifin, Ulfa, and Praherdhiono 2018) menjelaskan bahwa Indonesia merupakan negara Nusantara yang di dalamnya terdapat banyak sekali kebudayaan, akan tetapi hal tersebut mulai menghilang di kalangan masyarakat. Uuntuk mempertahankan dan melestarikan kebudayaan Indonesia salah satunya bisa melalui pendidikan.

Kurikulum muatan lokal tari Reog Kendang dikembangkan dengan memperhatikan berbagai aspek dalam pengembangan kurikulum muatan lokal yang telah disesuai dengan karakteristik pesertadidik.Widyastono menjelaskan bahwa pengembangan kurikulum harus menyesuaikan dengan potensi, perkembangan, kebutuhan, dan kepentingan siswa serta tuntutan lingkungan (Widyastono 2012). Jadi hal tersebut mengartikan bahwa pengembangan kurikulum harus terpusat pada siswa. Kurikulum muatan lokal tari Reog Kendang ini berisikan tentang pengetahuan/pemahaman dan praktek-praktek dalam kesenian Tari Reog Kendang. Kurikulum muatan lokal tari Reog Kendang ini terdiri dari silabus dan enam RPP. Dari hasil validasi silabus yang dilakukan oleh ahli kurikulum diperoleh presentase sebesar $83,6 \%$ yang berarti dalam penyusunan standar kompetensi, kompetensi dasar dan indikator sudah dalam katagori valid sedangkan dari ahli materi sebesar mendapatkan presentase sebesar $91,66 \%$ yang dapat dikatakan dalam penyusunan materi yang ada pada kurikulum muatan lokal tari reog kedang sudah dalam katagori valid sehingga dari data tersebut dapat disimpulkan bahwa silabus kurikulum muatan lokal tari Reog Kendang dapat dikatakan valid dan layak untuk digunakan.

Hasil validasi RPP yang dilakukan oleh guru muatan lokal diperoleh hasil presentase RPP ke 1 sebesar 93,33\%, RPP ke 2 sebesar 90\%, RPP ke 3 sebesar 90\%, RPP ke 4 sebesar $90 \%$, RPP ke 5 sebesar 88,33\% dan RPP ke 6 sebesar $90 \%$ dan dapat disimpulkan bahwa RPP kurikulum muatan lokal tari Reog Kendang sudah layak dan dapat digunakan. Ada beberapa hal yang menjadi masukan dari guru muatan lokal berkaitan dengan RPP kurikulum muatan lokal tari Reog Kendang yaitu perlunya penambahan beberapa bahan ajar dan sumber belajar yang digunakan dalam pelaksanaan pembelajaran.

Pengembangan kurikulum muatan lokal memutuhkan tingkat ketajaman analisis para guru. Guru harus cermat melihat potensi lokal yang belum diangkat sebagai sebuah inovasi yang dapat diajarkan sebagai muatan lokal. Beberapa negara menggunakan kurikulum muatan lokal dalam implementasi kurikulum berbasis sekolah (Yuen, Boulton, and Byrom 2018; Mulemwa 2002; Tan et al. 2017; Diem et al. 2016).

Untuk mewujudkan hal tersebut perlu dukungan dari berbagai pihak, baik internal sekolah maupun dukungan dari masyarakat dan dinas pendidikan (Priestley and Drew 2017). Di Indonesia implementasi kurikulum muatan lokal mulai berkembang sejak dibelakukan kurikulum tingkat satuan pendidikan tahun 2006 (Samsudi, n.d.; Yustisia 2008; Efendi 2009; Trianto 2010). 


\section{SIMPULAN}

Produk dalam penelitian pengembangan ini adalah berupa kurikulum muatan lokal tari Reog Kendang yang terdiri dari Silabus dan RPP yang valid dan layak untuk digunakan. Adanya pengembangaan kurikulum muatan lokal tari Reog Kendang dapat menjadi solusi sebagai sarana dan manfaat bagi sekolah dalam melestarikan dan mengembangkan budaya keariafan lokal daerah khususnya di Kabuaten Tulungagung. Kurikulum muatan lokal ini mempunyai beberapa keunggulan dimana materi pembelajaran telah disusun secara berurutan dan kemudahan bagi guru dalam memahami rencana pelaksanaan pembelajaran sebagai pedoman dalam melaksanakan pembelajaran muatan lokal.

Dalam proses pengembangan kurikulum muatan lokal diperlukan identifikasi secara menyeluruh tentang kebutuhan muatan lokal dan materi yang digunkan dalam pengembangan kurikulum muatan lokal tersebut, karena hal itu sangat penting dilakukan untuk memudahkan dalam proses pengembangan lebih lanjut. Selain itu juga untuk pengembangan kurikulum muatan lokal harus melihat dari segi kondisi dan karakteristik tempat yang digunkan dalam pengembangan kurikulum.

\section{DAFTAR RUJUKAN}

Ahmadi, Iif Khoiru, Sofan Amri, and Tatik Elisah. 2012. "Mengembangkan Pendidikan Berbasis Keunggulan Lokal Dalam KTSP.” Jakarta: Prestasi Pustaka.

Amaliah, Dini. 2016. "Pengembangan Muatan Lokal Sebagai Salah Satu Strategi Menghadapi Masyarakat Ekonomi Asean (Mea)." Jurnal Pendidikan Ekonomi Indonesia 1: 419-613.

Arifin, Zaenal. 2014. Konsep Dan Pengembangan Model Kurikulum. Jakarta: PT Remaja Rosdakarya.

Arifin, Zainul, Saida Ulfa, and Henry Praherdhiono. 2018. "Pengembangan Kurikulum Muatan Lokal Karawitan Sebagai Upaya Mengkonstruksi Pengetahuan Dan Pelestarian Budaya Jawa Di Jenjang SMA.” Jurnal Kajian Teknologi Pendidikan 1 (2): 123-32.

Diem, Chuzaimah D, Yusfardiyah Yusfardiyah, Binti Koniaturrohmah, and Lismalayani Lismalayani. 2016. "Implementation of School-Based Curriculum as Perceived by Secondary School Teachers of English." Indonesian Journal of Applied Linguistics 5
(2): 167-75.

Efendi, Mohammad. 2009. "Kurikulum Dan Pembelajaran: Pengantar Ke Arah Pemahaman KBK, KTSP, Dan SBI." Malang: Universitas Negeri Malang.

Kairupan, Siska B. 2015. "Pengembangan Bahan Pembelajaran Pariwisata Sebagai Mulok Pada Siswa SLTP Di Kabupaten Minahasa Sulawesi Utara." Jurnal Inovasi Dan Teknologi Pembelajaran 1: 155-64.

Mulemwa, Jane N. 2002. "School-Based Curriculum Development: A Proposal for Improving Girls' Performance in SMT."

Pratama, Indra Kurniawan, Anselmus J E Toenlioe, and Saida Ulfa. 2018. "Pengembangan Kurikulum Muatan Lokal Tari Boran Sebagai Langkah Pelestarian Kebudayaan Lamongan Pada Jenjang Sekolah Menengah Pertama.” Jurnal Kajian Teknologi Pendidikan 1 (2): 103-8.

Priestley, Mark, and Valerie Drew. 2017. "Teacher Sense-Making in School-Based Curriculum Development through Critical Collaborative Professional Enquiry." In A Companion to Research in Teacher Education, 769-83. Springer.

Purwanti, Elly. 2013. "Peningkatan Kemampuan Guru Sekolah Dasar Muhammadiyah Dalam Pengembangan Kurikulum Muatan Lokal.” Jurnal Pemikiran Dan Pengembangan Sekolah Dasar (JP2SD) 1 (1): 15-21.

Rokhim, Nur. 2013. "Makna Simbolik Tari Reyog Gembluk Tulungagung." Gelar: Jurnal Seni Budaya 11 (2).

Rosala, Dedi. 2017. "Pembelajaran Seni Budaya Berbasis Kearifan Lokal Dalam Upaya Membangun Pendidikan Karakter Siswa Di Sekolah Dasar." Ritme 2 (1): 16-25.

Samsudi, S. n.d. "Model Pengembangan Dan Implementasi Kurikulum Tingkat Satuan Pendidikan (KTSP) Berbasis Dukungan Stakeholders Pada Jenjang Pendidikan Dasar Dan ...." Jurnal Pendidikan Dan Pembelajaran Universitas .... https://www.neliti.com/publications/119808/m odel-pengembangan-dan-implementasikurikulum-tingkat-satuan-pendidikan-ktsp-ber.

Tan, Liang See, Elizabeth Koh, Shu Shing Lee, Letchmi Devi Ponnusamy, and Keith Chiu Kian Tan. 2017. "The Complexities in Fostering Critical Thinking through SchoolBased Curriculum Innovation: Research Evidence from Singapore." Asia Pacific Journal of Education 37 (4): 517-34.

Toenlioe, Anselmus J E. 2017. "Pengembangan Kurikulum.” Cetakan Ke-1. Bandung: PT Refika Aditama.

Trianto, M Pd. 2010. "Model Pembelajaran Terpadu: Konsep, Strategi, Dan Implementasinya Dalam Kurikulum Tingkat Satuan Pendidikan 
88 JINOTEP (Jurnal Inovasi dan Teknologi Pembelajaran) Kajian dan Riset dalam Teknologi Pembelajaran Vol. 6, No. 2, April 2020, Hal. 81-88

(KTSP).” Kuala Lumpur: Kemetrian Pengajaran Malaysia.

Utari, Unga, I Nyoman Sudana Degeng, and Sa'dun Akbar. 2016. "Pembelajaran Tematik Berbasis Kearifan Lokal Di Sekolah Dasar Dalam Menghadapi Masyarakat Ekonomi Asean (MEA)." Jurnal Teori Dan Praksis Pembelajaran IPS 1 (1): 39-44. https://doi.org/10.17977/um022v1i12016p039. Widwi, Astuti. 2017. Reog Kendang Tulungagung. Kediri: FAM Publising.

Widyastono, Herry. 2012. "Muatan Pendidikan Holistik Dalam Kurikulum Pendidikan Dasar Dan Menengah.” Jurnal Pendidikan Dan
Kebudayaan 18 (4): 467-76.

Yuen, S, H Boulton, and T Byrom. 2018. "SchoolBased Curriculum Development as Reflective Practice: A Case Study in Hong Kong." Curriculum Perspectives 38 (1): 15-25.

Yustisia. 2008. "Panduan Lengkap KTSP (Kurikulum Tingkat Satuan Pendidikan).” Yogya arta: Pusta a Yustisia.

Zubaidi, Ahmad. 2015. "Model-Model Pengembangan Kurikulum Dan Silabus Pembelajaran Bahasa Arab." Cendekia: Jurnal Kependidikan Dan Kemasyarakatan 13 (1): 107-22. 